\title{
Biostimulating Action of Low-Intensity Monochromatic Visible Light: Is it Possible?
}

\author{
T. I. KARU, O. A. TIPHLOVA and G. E. FEDOSEYEVA \\ Laser Technology Center, USSR Acad of Sciences, Moscow Region, Troitzk, 142092 \\ USSR
}

\section{G. S. KALENDO}

Cancer Research Center, USSR Acad. Med. Sci., Moscow, 114456 USSR

\section{S. LETOKHOV and V. V. LOBKO}

Institute of Spectroscopy, USSR Academy of Sciences, Moscow Region, Troitzk, 142092 USSR

T. S. LYAPUNOVA, N. A. POMOSHNIKOVA and M. N. MEISSEL Institute of Microbiology, USSR Academy of Sciences, Moscow USSR

(Received 17 February 1984)

The quantitative studies with organisms of different complexity (HeLa cells, yeast organisms, $E$ coli bacteria) to prove or disprove the stimulating action of low-intensity visible light are presented. The stimulation of DNA synthesis in HeLa cells was observed for four spectral intervals with maxima at near $400,620,680$ and $760 \mathrm{~nm}$. The red light stimulates the growth of yeast (Saccharomycodes ludwigii) and $E$ coli in exponential growth phase. The action spectrum of monochromatic light on the growth of these organisms in the red region is very similar to that for HeLa cells.

Last years the low intensity (noncoagulative) visible laser radiation has been successfully used in some areas of medicine (photodynamic therapy of tumours, therapy of infant hyperbilirubinemia, some dermatological diseases, etc). ${ }^{1}$ Also the therapy with red $(632.8 \mathrm{~nm})$ laser light (stimulation of tissue regeneration) used for irradiation of the 
patients with trophic and indolent wounds has gained acceptance in the clinical practice. ${ }^{2-4}$ But there are still many doubts among scientists about the existence of that kind of stimulation.

Indeed, the healing effect of red light is often attributed to a psychological action. From the physical standpoint the effect of biostimulation seems improbable since it is difficult to explain particular sensitivity of biological objects to the irradiation with red light as compared to the systematic irradiation with white light, the spectrum of which contains a red component approximately of the same power.

Clinicians often discuss a particular role of laser light coherence to explain its biological action. This argument does not seem reasonable because the rate of molecular excitation with low-intensity light is many orders $\left(10^{10}-10^{14}\right.$ times) lower than the coherence loss rate of the excited molecular states in the condensed phase at normal temperature.

We have made an attempt to perform quantitative studies with organisms of different complexity to prove or disprove the stimulating action of low-intensity red light. Two types of eucariotic cells-human cells and yeast organisms as well as one type of procariotic cellsbacteria E. coli, have been chosen as the objects of investigation. The rate of the DNA synthesis in human cells, the rate of reproduction of microorganisms were controlled for estimation of the action of irradiation.

\section{MONOCHROMATIC LIGHT IN VISIBLE RANGE CAN STIMULATE THE DNA SYNTHESIS IN MAMMALIAN CELLS}

Since nucleic acids themselves do not absorb visible light, the changes in the synthesis rate of DNA after its irradiation with light indicate deep changes in the cells vital activity after absorption of light by any chromophore.

At first we investigated the dose-response relationship after the irrdiation of the culture of HeLa cells with coherent and incoherent red light (Figure 1). We found that in conditions of our experiment both types of red light stimulate DNA synthesis from the fluence of $10 \mathrm{~J} \cdot \mathrm{m}^{-2}$ with maximum at fluence $100 \mathrm{~J} \cdot \mathrm{m}^{-2}$. No essential differences were observed between the results obtained for coherent and incoherent light sources. 


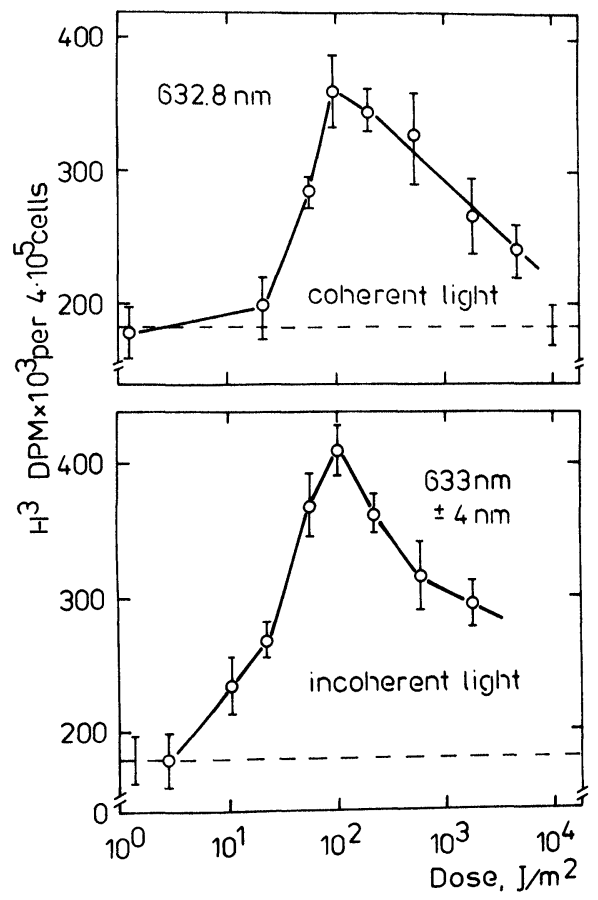

FIGURE 1 The stimulation of DNA synthesis in HeLa cells after irradiation with coherent (He-Ne Laser, $\lambda=632.8 \mathrm{~nm}$, Figure a) and incoherent light (incadescent filament lamp with monochromator, $\lambda=633 \mathrm{~nm}, \Delta \lambda=8 \mathrm{~nm}$, Figure 8). The dashed lines denote the control level (nonirradiated cells). HeLa cells at logarithmic state of growth were cultivated in scintillation vials in $2 \mathrm{ml}$ of 199 medium supplemented with $15 \%$ bovine serum and antibiotic ( 100 units $/ \mathrm{ml}$ canamycine). The light beam was expanded by a set of lenses to the diameter of the flask bottom $(2.4 \mathrm{~cm})$ covered with a monolayer of cells $\left(4 \cdot 10^{5}\right.$ cells $72 \mathrm{~h}$ after seeding). The irradiation was performed in darkness and the temperature was kept all time at $37^{\circ} \mathrm{C}$. The output power of $\mathrm{He}-\mathrm{Ne}$ laser was $40 \mathrm{~mW}$, the light intensity was reduced from 0.6 to $90 \mathrm{~W} / \mathrm{m}^{2}$. The power density of lamp was 1.5 and $25 \mathrm{~W} / \mathrm{m}^{2}$, the dose was reached by irradiating the cells during $2 \mathrm{~s}$ to $60 \mathrm{~s}$. The incorporation of $\mathrm{H}^{3}$-thymidine (concentration of $5 \mu \mathrm{Ci} / \mathrm{ml}$, Sp.act. $26 \mathrm{Ci} / \mathrm{mM}$ ) was investigated with radiometric technique by pulse labelling for $20 \mathrm{~min}$ at $t=37^{\circ} \mathrm{C}$.

So, there exists a stimulation of DNA synthesis in cellular culture after the irradiation with monochromatic red light at $633 \mathrm{~nm}$. Such properties of light as coherence and polarization do not play a role in this effect. 
If there is such an effect of stimulation at wavelength $633 \mathrm{~nm}$, is it possible to stimulate DNA synthesis with light of other wavelengths in the visible spectrum? To clarify this question we measured the action spectrum of monochromatic light on DNA synthesis over the entire visible region using incandescent filament lamp or mercury lamp and monochromator as a source of tunable light.

DNA synthesis was stimulated in four spectral regions with maxima at about $400 \mathrm{~nm}, 620 \mathrm{~nm}, 680 \mathrm{~nm}$ and $760 \mathrm{~nm}$ (Figure 2a). It means that "red light syndrome", i.e., stimulation with red light (used in medicine) can be accomplished with relatively monochromatic irradiation at other wavelengths too. On the other hand, such a character of action spectrum points to the fact that cell has one or, most likely several acceptors of light in the visible range. One of them may be any porphyrin-containing enzyme, like catalase, having absorption bands in these regions. ${ }^{5}$

Another possibility is that there exist a special light absorbing chromophore (chromophores) in eucariotic cell, like phytochrome for red light in plants ${ }^{6}$ or so called "kryptochrome" for blue light in microorganisms. ${ }^{8}$ So far the existence of such specialized chromophore in the mammalian cells is not confirmed, although such an assumption has been made. ${ }^{7}$ In any case, the primary photochemistry and photophysics including the quesion about the chromophore, as well as the mechanisms of realization (metabolic, conformational etc. changes in the cell after the primary act of absorption) are not clear.

\section{RED LIGHT CAN STIMULATE THE GROWTH OF YEAST AND BACTERIA}

The next natural step of our research was to understand the ability of the red light to stimulate the vital activity of primitive eucariotic cells when there is no regulation at organism or population level. We have found earlier, ${ }^{10}$ that the irradiation with He-Ne laser $(\lambda=633)$ can stimulate the reproduction rate and synthesis of biomass in two types of yeast. Using the experimental conditions described in, ${ }^{10}$ we measured now the action spectrum of the stimulation of Saccharomycodes ludwigii yeast growth (Figure $2 \mathrm{~b}$ ). In this action spectrum there are two bands where the stimulation of growth was observed-near 640 and $680 \mathrm{~nm}$. 


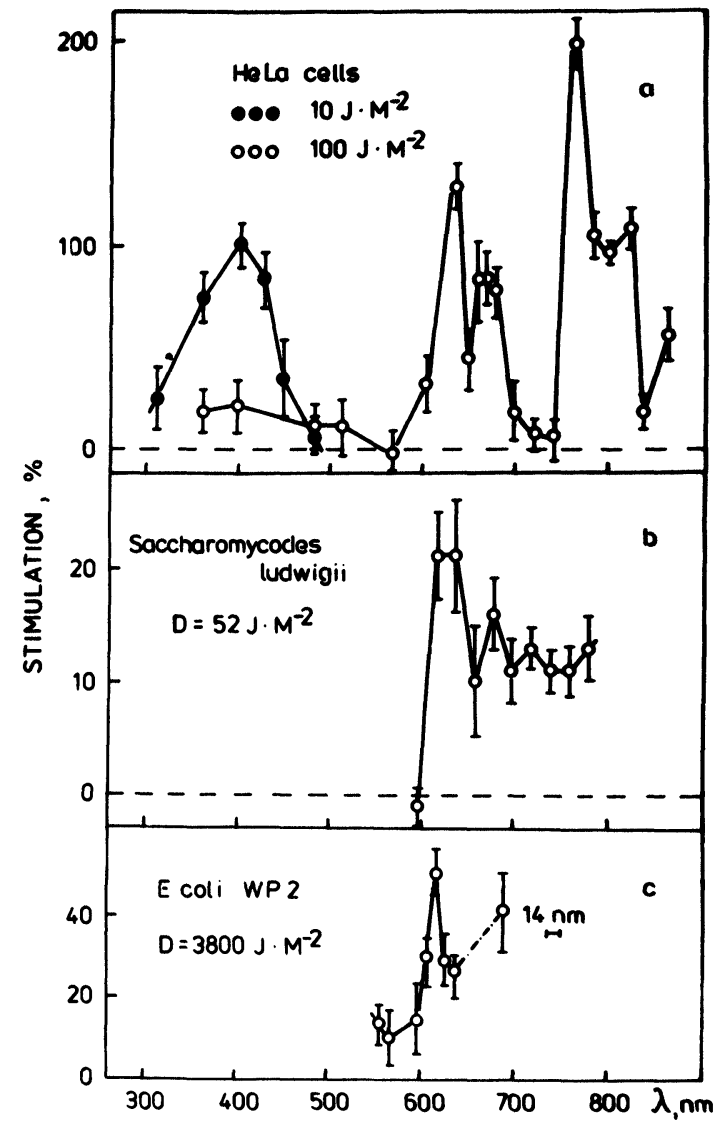

FIGURE 2 The action spectrum of visible light on DNA synthesis in HeLa cells (a), on yeast growth (b) and $E$ coli growth (c). The dashed lines denote the control level (without irradiation). The radiation wavelengths were obtained by using monochromator with incandenscent $(400-860 \mathrm{~nm})$ lamp. Yeast cells were grown for 5 hours in wort $(7 \mathrm{Bal})$ in rocker-mounted flasks, then separated from the nutrient medium by centrifugation and washed twice with sterile tap water. $5 \cdot 10^{7}$ cells were placed in Petri dishes with agar-wort and 2 hours later cells were irradiated during $10 \mathrm{~s}$ at room temperature. Then yeast were grown during $14-16$ hours at the $28^{\circ} \mathrm{C}$. The suspension of three time washed cells was hydrolised with $\mathrm{NaOH}(0.1 \mathrm{M})$ in a boiled water bath for $10 \mathrm{~min}$. The content of protein in hydrolasate thus obtained was determined by the Low $r y$ method.

Logarithmic phase cultures of $E$ coli WP2 were irradiated in $0.05 \mathrm{M}$ phosphate buffer, then the rich medium was added and cells were incubated at $37^{\circ} \mathrm{C}$ during 1.5 hours. After the incubation the samples were taken, diluted and spread on plates of rich medium solidified with Bacto agar. The visual count of the colonies was made after $24 \mathrm{~h}$ of incubation. 
Since it has been found that the vital activity of eucariotic cells was stimulated under some wavelengths of visible light irradiation, it was interesting to know how procariotic cells would respond to this type of irradiation. Using the dose $4 \cdot 10^{3} \mathrm{~J} \cdot \mathrm{m}^{-2}$, what was found to be optimal for stimulating action, ${ }^{9}$ we have measured the action spectrum of light on the growth of $E$ coli WP2 in the red region of visible light $(550-650 \mathrm{~nm})$ (Figure 2c). Growth stimulation measured by counting the number of colonies, can be observed in a range of 610 to $640 \mathrm{~nm}$ with the maximum at $620 \pm 7 \mathrm{~nm}$.

\section{CONCLUSION}

In our experiments we have found that low-intensity red light, both coherent and incoherent, under certain conditions (dose, wave-length) can stimulate the vital activity of both procariotic and eucariotic cells. For bacteria the observed effect is maximal at a dose $\simeq 50$ times higher $\left(5 \cdot 10^{3} \mathrm{~J} / \mathrm{m}^{2}\right)$ than for human cells $\left(100 \mathrm{~J} / \mathrm{m}^{2}\right)$.

All the observed effects are final macroeffects. The processes of primary photochemistry (light quantum absorption and signal transfer) and the mechanisms of realization (modification of metabolic pathways in cells) are still not clear. The presence of a characteristic spectrum of action qualitatively similar for procariotic and eucariotic cells in a region of 550 to $650 \mathrm{~nm}$ could indicate that there should exist a common way of low-intensity red light action.

\section{References}

1. R. Pratesi and C. A. Sacchi, eds., Laser in Photomedicine and Photobiology, Springer Series in Optical Sciences, Vol. 22 (Springer-Verlag, Berlin-Heidelberg-New York, 1980).

2. N. F. Gamaleya, in: Laser Applications in Medicine and Biology, Vol. 3, ed. by M. Wohl-barsht (Plenum Press, New York, London, 1977) pp. 54-175.

3. E. Mester, E. J. Nagy, E. Bascy et al., in: Medizinische Physik in Forschung und Praxis, ed. A. Kaul (Walter de Gruyter, Berlin 1976) pp. 117-135.

4. J. S. Kana, G. Hutschenreiter, D. Haina and W. Waidelich, Arch. Surg. 116, 293 (1981).

5. D. M. Kirschenbaum, ed., Atlas of Protein Spectra in the Ultraviolet and Visible Regions, (IFI Plenum, New York, Washington, London, 1972).

6. H. Smith, Phytochrome and Photomorphogenesis (McGraw-Hill Book Company, London, 1975).

7. S. A. Gordon and K. Surrey, Rad. Research 12, 325 (1960). 
8. H. Senger, ed., The Blue Light Syndrome (Springer-Verlag, Berlin, Heidelberg, New York, 1980).

9. T. I. Karu, O. A. Tiphlova, V. S. Letokhov and V. V. Lobko, Nuovo Cimento 2D, N3 (1983).

10. G. E. Fedoseyeva, T. I. Karu, V. S. Letokhov, V. V. Lobko, N. A. Pomoshnikova, T. S. Lyapunova and M. N. Meissel, Int. J. Laser Chemistry 5, 1 (1984). 